\title{
Aspectos da religiosidade brasileira em À Meia-Noite Levarei sua Alma
}

\section{Carlos Gerbase}

Pontifícia Universidade Católica do Rio Grande do Sul, Escola de Comunicação, Arte e Design, Porto Alegre, RS, Brasil

ORCID: https://orcid.org/0000-0001-9215-5840

\section{Giancarlo Backes Couto}

Pontifícia Universidade Católica do Rio Grande do Sul, Escola de Comunicação, Arte e Design, Porto Alegre, RS, Brasil

ORCD: https://orcid.org/0000-0001-9757-522X

\section{Resumo}

Este artigo busca destacar alguns aspectos da religiosidade brasileira no filme À Meia-Noite Levarei sua Alma, de José Mojica Marins, lançado em 1964, e compreender como esses elementos são utilizados na obra para causar o medo nos espectadores. O trabalho parte dos Estudos Culturais para entender esse processo de constituição da matriz religiosa brasileira no imaginário da população do país. Por fim, foram escolhidas algumas cenas do filme em que esses elementos religiosos se apresentam, a fim de serem investigadas através da análise fílmica, para entender como esses elementos são articulados e representados. Como conclusão, se percebe que o filme utiliza as crenças de seus espectadores para provocar sua curiosidade e êxtase em relação a saga de Zé do Caixão.

\section{Palavras-chave}

À Meia-Noite Levarei sua Alma. José Mojica Marins. Religiosidade brasileira. Estudos Culturais. Cinema.

\section{Introdução}

O intuito desse trabalho é entender como se articulam aspectos da religiosidade brasileira dentro do primeiro filme de horror de José Mojica Marins, À meia-noite levarei sua alma1 ${ }^{1}$ Para tal aporte, os Estudos Culturais foram utilizados como norte, a fim de fazer essa ligação entre a cultura e o que dela se reproduz no filme.

Para entender o que é a religiosidade brasileira, se buscou traçar sua gênese no processo de colonização do país, no século XVI, com a vinda de europeus católicos para o 
Brasil e o encontro dos mesmos com os habitantes locais. Do mesmo modo, o trabalho destaca como outras religiões, como o candomblé e o espiritismo, tiveram sua importância no processo de produção da matriz religiosa brasileira, formada pelo sincretismo religioso, os encontros e tensões de diversas culturas e crenças no país.

Todo esse processo da constituição brasileira se traduz também no desdobramento da constituição dos medos de um povo e é esse enlace que este artigo busca para relacionar e entender como a religiosidade brasileira se manifesta naquele que é considerado o primeiro filme de horror do país. Sendo o medo a emoção central em um filme desse gênero, este trabalho tenta entender como seu diretor, José Mojica Marins, utilizou em sua película essa mesma religiosidade nacional para trabalhar os medos advindos dela.

Deste modo, o artigo parte de pressupostos dos Estudos Culturais, para trabalhar a relação do objeto com a cultura, visto que, a cultura não é recebida de modo passivo pelos indivíduos, mas sim com diversas intervenções ativas, principalmente através dos discursos e representações (AGGER, $1992^{2}$ apud ESCOSTEGUY, 2015). Assim também, Williams (2011) defende que “[...]não se pode entender um projeto intelectual ou artístico sem que também se compreenda a sua formação [...]" (WILLIAMS, 2011, p. 172). Aqui, Williams (2011) destaca a importância de se entender ambos, o objeto em si e sua formação, sem focar apenas em um ou em outro, ou simplesmente colocar o objeto como exemplo da sociedade. 0 intuito é buscar entender a formação e direcionamento que alimentam essa relação. Por isso, o foco deste trabalho é relacionar o objeto em si (o filme À meia-noite levarei sua alma) com a sua formação e inserção no universo cultural de sua época. Nesse sentido, é fundamental compreender a formação da religiosidade brasileira e, ao analisar um filme de horror, apreender a importância desse sistema de crenças na constituição dos medos de determinada cultura.

\section{A religiosidade brasileira e a formação do medo}

A religiosidade brasileira é marcada pelo seu sincretismo, fruto da fusão de vários elementos diferentes misturados desde a colonização do país. A partir disso é possível se falar da matriz religiosa brasileira, sendo ela um objeto de estudo que busca entender as relações complexas entre as diversas religiões que constituem a religiosidade brasileira.

${ }^{2}$ AGGER, Bem. Cultural studies as critical theory. Londres/Washington DC: The Falmer Press, 1992. Apud Escosteguy (2015). 
Cumpre indagar a esta altura quais foram os principais elementos que se 'fundiram' na composição da Matriz Religiosa Brasileira. Para tanto, em primeira instância e em termos muito sucintos, basta recorrer à formação histórica da nacionalidade: com os colonizadores chegam o catolicismo ibérico (reconhecidamente singular) e a magia europeia. Aqui se encontram com as religiões indígenas, cuja presença irá impor-se por meio da mestiçagem. Posteriormente, a escravidão trouxe consigo as religiões africanas que, sob determinadas circunstâncias, foram articuladas num vasto sincretismo. No século XIX, dois novos elementos foram acrescentados: o espiritismo europeu e alguns poucos fragmentos do Catolicismo romanizado. (BITTENCOURT FILHO, 2003, p. 41).

Apesar de todo esse sincretismo, fica claro que a religião predominante no país acabou por ser a católica. No censo feito pelo IBGE no país, investigando um panorama das religiões brasileiras entre 2000 e 2010 , mais de $86 \%$ da população se identifica com alguma religião cristã (católica e evangélica). Pensando numa perspectiva histórica, o números de cristãos no país são ainda maiores:

Desde o primeiro recenseamento de âmbito nacional até a década de 1970, o perfil religioso da população brasileira manteve como aspecto principal a hegemonia da filiação à religião católica apostólica romana, característica herdada do processo histórico de colonização do País e do atributo estabelecido de religião oficial do Estado até a Constituição da República de 1891. As demais religiões praticadas no Brasil, resultantes dos vários grupos constitutivos da população, tinham contingentes significativamente menores. (IBGE, 2010, p. 89).

Mesmo com a queda do percentual daqueles que se consideram católicos, entre os anos 1970 e o último censo, o número de evangélicos aumentou expressivamente, demonstrando que a população permaneceu sob a égide do cristianismo. As bases genealógicas, contudo, permanecem sendo as do catolicismo.

Se nossa formação religiosa foi católica, isso se deve muito à reestruturação promovida no Concílio de Trento, série de reuniões eclesiais ocorrida entre os anos de 1545 e 1563. Adaptando-se ao caráter revolucionário das reformas, a Igreja Católica conseguiu se manter hegemônica e sobreviveu à modernidade, ancorando-se na disciplina e tradição. Não é por acaso o caráter centralizador e militarizado de suas ordens, como a Companhia de Jesus, e a forte presença de líderes espanhóis e portugueses nesse momento. 0 salto para o Novo Mundo se deu através da península ibérica e das missões jesuíticas, com um modelo de evangelização que se manteve até o século XX. 0 controle social aqui se dá através de uma lógica baseada na divulgação das obras penitenciais, das festas religiosas, dos sermões 
fervorosos e das altas arrecadações monetárias na Europa e Américas. Não há espaço para contestação em meio a toda repressão sistemática produzida (PEREIRA, 1991).

\begin{abstract}
[...] a experiência colonial moderna dos ibéricos de certa forma prolongou sua experiência colonial medieval, com a conquista da América aos pagãos indígenas correspondendo à reconquista da península aos 'pagãos'mouros. 0 tradicional grito guerreiro desta, invocando Santiago, foi utilizado naquela, por exemplo no Maranhão em princípios do século XVII. Nos dois casos, o processo não foi obra dos setores mais progressistas da sociedade, embora estes tenham a partir de um segundo momento se beneficiado dele. Enquanto a colonização inglesa da América foi realizada por segmentos sociais 'modernos', gente que buscava novos horizontes, a colonização portuguesa foi obra de setores ainda 'medievais', que pretendiam reproduzir em outro palco, mais amplo e rico, o enredo histórico anterior. (FRANCO JÚNIOR, 2008, p. 83).
\end{abstract}

Como Franco Júnior (2008) enfatiza, desde a composição de seu relatório ao rei, Pero Vaz de Caminha já se mostrava entusiasmado com a possibilidade de fácil evangelização dos índios, estes, segundo ele, que não tinham nem entendiam crença alguma. Assim, a colonização toma ares de uma nova cruzada, uma nova chance de conquista religiosa e expansão do catolicismo já tentados antes no Oriente. Posteriormente, inclusive, um respiro de alívio diante das ameaças da reforma protestante em curso na Europa.

Freyre (2006) relembra que no Brasil nunca houve uma busca por uma pureza de raça e que durante todo o século XVI o país esteve escancarado para os estrangeiros que quisessem entrar. A única exigência, porém, era que fossem cristãos. “O perigo não estava no estrangeiro nem no indivíduo disgênico ou cacogênico, mas no herege." (FREYRE, 2006, p. 91).

É nesse momento que se firma a Inquisição em Portugal e em suas colônias. O que começou como perseguição de divergências religiosas, passa a ter seu caráter moral na perseguição de supostos feiticeiros, bruxas, bígamos e pederastas. As torturas e conversões forçadas de judeus do século XIII retornam em forma de caça aos marginalizados no século XVI, começando na Espanha, passando para Portugal e se estendendo às colônias na América Latina.

Introduzida em Portugal em 1547, subordinada à autoridade monárquica, a Inquisição chegou ao Brasil em fins do século XVI com a mesma função controladora das consciências e repressora de idéias não-oficiais. Toda diferença deveria ser anulada: Vieira sonhava com o momento em que os portugueses poderiam banhar suas espadas no sangue dos hereges na Europa, no sangue dos muçulmanos na África, 'no sangue dos pagãos na Ásia e na América'. A atuação da Inquisição tanto na metrópole portuguesa 
quanto na colônia americana parece ter introduzido na psicologia coletiva uma 'razão da força' que não deixaria de ser utilizada séculos depois em certos momentos da vida política dos dois países.

Como bem viu Laura de Mello e Souza, na nossa história a intolerância é legado colonial, ao que é preciso acrescentar que esta tinha, por sua vez, inegáveis origens medievais. (FRANCO JÚNIOR, 2008, p. 96).

Por outro lado, Araújo (2016), ao analisar processos jurídicos contra supostos feiticeiros, no Brasil colonial, destaca que no caso da Inquisição portuguesa, as forças coercitivas da igreja se deram muito mais pelo medo, pelo constante temor e construção de imaginário do que pela própria força física e tortura violenta. A igreja, nesse momento, atuava mais na consciência e gerava um sentimento de separação e vigília entre as pessoas. A prática das visitas episcopais caracterizava o ápice desse momento, quando os homens da igreja chegavam a algum local questionando sobre os pecadores dali. As acusações partiam dos próprios membros da comunidade, aumentando o sentimento de desconfiança entre todos. Geralmente os acusados se declaravam culpados, a fim de fugir das punições e implorar por misericórdia. Araújo (2016) evidencia que geralmente esses pedidos eram acatados, o que faz sobressair esse intuito de correção moral da inquisição moderna. Outro ponto a se destacar nesse viés é que essas visitas eram sempre divulgadas com antecedências, o que dava a oportunidade das pessoas se entregarem e pedirem remissão de seus pecados antes mesmo da denúncia.

Todos esses pontos específicos servem para reafirmar a visão já debatida por pesquisas historiográficas de que a Inquisição Moderna buscava muito mais lidar com os católicos batizados que se desviavam do caminho do que com pessoas de outras religiões. 0 imaginário de medo suscitado na época da colonização era transmitido por livros, sermões e pela ação repressora da evangelização. Além disso, o cotidiano em si se via imerso nessa cultura do fantástico, onde a própria justiça laica se confundia com a sacra e até livros de medicina eram dedicados contra forças ocultas (ARAÚJO, 2016). Soma-se a isso a impressão de culpa e julgamento constante, com a vigilância tanto do Estado, quanto da Igreja e também dos próprios vizinhos. Não é por acaso que os próprios inquisidores se viam como salvadores misericordiosos e aqui no Brasil poucos foram as condenações à morte. A angústia era o caminho escolhido e o controle pela consciência se mostrava muito mais efetivo.

O que se nota é que tudo isso se articula em torno da noção do medo. Bittencourt Filho (2003) destaca que em todo o processo de colonização, as massas eram constituídas, num geral, por pessoas de pouca visão crítica. "A descrença era algo absolutamente estranho 
na cosmovisão da época, as maiorias estavam sempre propensas a 'acreditar' [...]" (BITTENCOURT FILHO, 2003, p. 47), o que favorecia essa visão de que tudo tinha contornos de magia, de sobrenatural. Ao mesmo tempo, essas pessoas vinham de uma cultura que via o mundo como lugar onde havia paraísos terrestres, mas também terras habitadas por monstros e demônios. Nesse caso, o Brasil era visto muitas vezes como o encontro desses dois mundos, um paraíso natural na Terra, mas também um local habitado por diversos monstros e criaturas demoníacas. Nesse sentido, os moradores locais, indígenas, eram vistos como 'semidemônios', que precisavam de conversão e salvação. Freyre (2006) também destaca que na infância, o menino brasileiro da colônia convivia com todo tipo de lenda sobre monstros e demônios de diversas origens.

Após isso, no processo de escravidão, as religiões dos africanos trazidos para o Brasil acabaram por tornar essa matriz religiosa brasileira num sistema ainda mais complexo. Tendo suas práticas religiosas suprimidas por ordem de seus senhores, os escravos camuflaram seus ritos e crenças justapondo orixás e santos católicos. Ao mesmo tempo, os escravos acolheram alguns conteúdos de religiões indígenas e buscaram também contornar diferenças muito grandes entre suas diversas religiões ancestrais. Como esses escravos vinham de variados lugares do continente africano, díspares em suas culturas, buscaram assim também se unificar através do catolicismo. Por isso que em diversos quilombos os cultos africanos eram proibidos e os católicos eram os usuais. 0 catolicismo funcionava assim como um elo de união entre os diferentes povos africanos.

Sendo assim, a matriz religiosa brasileira é constituída por diversas religiões e marcada por seus sincretismos. Todavia, o catolicismo permaneceu como vigente, moldando a partir de suas visões o imaginário do brasileiro desde sua colonização. 0 medo, nesse sentido, se dá muitas vezes em relação às outras religiões que compõem essa matriz.

Apesar do foco do artigo ser a obra de José Mojica Marins, cumpre destacar aqui que ele não foi o primeiro nem o último a trazer questões religiosas para a arte. Para citar apenas alguns dos mais variados exemplos: talvez o quadro brasileiro mais famoso seja $A$ Primeira Missa no Brasil, de Vítor Meirelles, que retrata esse episódio descrito na carta de Pero Vaz de Caminha. Já nesse processo de descobrimento pelos portugueses, a religião tem um papel fundamental e sua representação artística se tornou um marco. 0 quadro de Meirelles, finalizado em 1861, não é o único a retratar a cena. Cândido Portinari, em 1948 e Glauco Rodrigues, em 1971, também estabeleceram sua visão sobre o evento (COUTO, 2008). No cinema, no mesmo período de Mojica, Glauber Rocha também debateu 
constantemente sobre a matriz religiosa brasileira, principalmente nos filmes Deus e o diabo na terra do sol ${ }^{3}$ e $O$ dragão da maldade contra o santo guerreiro ${ }^{4}$.

\section{0 horror em José Mojica Marins}

José Mojica Marins é um cineasta paulistano que ficou conhecido principalmente a partir de seu personagem Zé do Caixão e de seus filmes de terror, produzidos a partir da década de 1960 e considerados parte do movimento cinema marginal. Seus filmes eram feitos com baixo orçamento e participação de atores não profissionais, a maioria trabalhadores das classes mais baixas da cidade que buscavam se tornar estrelas de cinema. O próprio Mojica nunca teve formação nenhuma na área, apesar de filmar desde adolescente com seus amigos do bairro onde morava, em São Paulo. Não obstante seu personagem Zé do Caixão ser uma espécie de ateu niilista e seus filmes conterem diversos preceitos dessa ordem, Mojica é católico (SENADOR, 2008). Sendo um homem religioso, ele conhece muito bem todo esse universo, que é muito explorado em seus filmes.

Desde sua infância, Mojica foi tido como uma criança criativa e muito ligada ao universo fantástico. Seja por influência de sua vasta coleção de gibis, seja por frequentar diariamente o cinema em que o pai trabalhava e onde assistia diversos filmes e seriados, o garoto transformava suas inspirações em brincadeiras e peças de teatro com os amigos. Além disso, na Vila Anastácio, bairro de imigrantes de baixa renda de São Paulo, onde Mojica cresceu, era comum essa mistura de culturas e povos. Vindo de família católica, o garoto gostava de espiar com curiosidade os terreiros de candomblé e suas atividades. Além disso, sua própria família costumava frequentar o centro espírita do bairro e tentar a comunicação com parentes mortos (BARCINSKI; FINOTTI, 2015).

Essas influências já se notam na primeira tentativa do garoto e seus amigos de produção de um filme. 0 curta-metragem O Juízo Final, rodado em 1949, quando Mojica tinha 13 anos, conta a história de um ataque alienígena, com naves em formato de caixão que, com raios de luz, desintegravam o corpo de pessoas condenadas por seus pecados. Uma mistura de sci-fi com toques de punitivismo católico. Após isso, fizeram também $A$ Encruzilhada da Perdição e Feitiçaria, mistura de documentário e ficção de horror sobre um centro espírita da Vila Anastácio (BARCINSKI; FINOTTI, 2015).

${ }^{3}$ Este lançado, inclusive, no mesmo ano de À meia-noite levarei sua alma. Ficha do filme em IMDb ([2019b]). 
Apesar dessa influência, os dois primeiros longas-metragem de Mojica não foram do gênero horror ou fantástico. 0 primeiro, $A$ sina do aventureiro ${ }^{5}$, é uma espécie de western tupiniquim, enquanto o segundo, Meu destino em tuas mãos ${ }^{6}$, é um drama infantil. Esses filmes, porém, foram fracassos de bilheteria e crítica. A reviravolta de sua carreira veio quando Mojica investiu no cinema de horror. Sua estreia no gênero, em 1964, com À meianoite levarei sua alma, lançou seu personagem Zé do Caixão e foi sucesso entre o público e parte da crítica. Essa obra ainda o faria famoso fora do Brasil e o consagraria como cineasta cultuado por fãs do gênero no mundo todo.

Acom e Moraes (2017) classificam o cinema de Mojica como "horror caipira", justamente por lidar com esse imaginário do medo do interior:

Chamar de 'horror caipira' é uma licença poética que não visa diminuir o gênero, e nem a criação de José Mojica Marins, mas localizar em um imaginário que identifico como o interior paulista ou mineiro, onde as histórias agourentas de homens de preto, almas penadas e horror a cemitério, compunham o cotidiano, sobretudo ao anoitecer. 0 termo caipira invoca o conceito de cultura popular destas regiões do Brasil, e embora associado aos habitantes de um espaço rural, remete também a pessoas e seus conjuntos de crenças, muitas vezes caracterizados como superstição. (ACOM; MORAES, 2017, p. 30).

Esse é um dos principais motivos que colocam Mojica como um cineasta autenticamente brasileiro. Apesar de ter também influências do gênero importadas, como as histórias de terror clássicas europeias e suas adaptações estadunidenses, Mojica se consolidou dando tons completamente brasileiros aos seus filmes, se aproximando assim do público. O cineasta também foi um grande consumidor de histórias em quadrinhos, colocando diversos elementos das histórias de horror que faziam sucesso no país na época, tais como um personagem que introduz a história (elemento presente no começo de À meianoite levarei sua alma, que será destacado na análise seguinte), planos aproximados para realçar as expressões de personagens e também os fortes contrastes em preto e branco na fotografia do filme (MELO, 2010).

À meia-noite levarei sua alma conta a história de Zé do Caixão, um coveiro que vive numa pequena cidade do interior. Obcecado por gerar um filho perfeito, que será a continuidade de seu sangue, Zé faz de tudo para conquistar tal objetivo, inclusive assassina sua esposa infértil e estupra a esposa de seu melhor amigo, acreditando que ela é a mulher 
ideal para gerar seu filho. O filme é cheio de momentos violentos e tem fortes aspectos religiosos, principalmente no confronto entre Zé do Caixão, um niilista que zomba de todas as religiões e crenças locais, e os demais cidadãos da cidade, que lhe colocam a pecha de amaldiçoado e demônio.

\begin{abstract}
A essa altura, não pode haver dúvida de que À Meia-Noite Levarei sua Alma é um filme radical, tanto na forma como no conteúdo. E nada é mais radical no filme do que sua blasfêmia. À Meia-Noite é carregado de uma virulência anticristã extremada até para os padrões atuais. Zé do Caixão zomba de padres, ri da procissão santa e chama cristãos de 'idiotas'. Quando vê um crucifixo na parede, diz que aquilo não passa de um 'símbolo da ignorância'. Não é difícil de imaginar o choque que deve ter sido para o público suburbano paulista ouvir um personagem vomitando injúrias como essas. (BARCINSKI; FINOTTI, 2015, p. 177, grifo do autor).
\end{abstract}

O sucesso e polêmica em relação ao filme se deve diretamente a esses aspectos. Muitas pessoas se horrorizaram com a película e boatos se espalharam pela cidade, acusando Mojica de ter pacto com satanás. Mesmo que no final do filme Zé do Caixão se arrependa e seja punido com a morte pelos espíritos das pessoas a quem ele fez mal, o choque de todas as falas anti-religiosas causou espanto nos espectadores, principalmente aqueles mais apegados às suas crenças.

A partir daí Mojica focou em seus filmes de terror, sempre protagonizados ou contando com participações célebres de seu personagem Zé do Caixão. Em 1967 lançou a continuação de À meia-noite levarei sua alma, chamada Esta noite encarnarei no teu cadáver ${ }^{7}$. Após vieram $O$ estranho mundo de Zé do Caixão ${ }^{8}$, Trilogia de terror ${ }^{9}$ e $O$ ritual dos sádicos ${ }^{10}$, este último completamente proibido pela censura.

Um dos principais indicadores de que os filmes de Mojica incomodavam a moral religiosa de sua época era a censura que recebiam. Geralmente os relatórios dos censores apontavam que seus filmes eram subversivos e iam contra os preceitos de uma sociedade baseada em Deus e na família. As cenas violentas incomodavam, algumas eram até cortadas, mas o principal sempre se atinha a dar um final punitivo a Zé do Caixão, o grande crítico da moral. Um dos casos mais célebres é o final de Esta noite encarnarei no teu cadáver, que originalmente terminava com Zé do Caixão morrendo enquanto amaldiçoava um padre. Os

\footnotetext{
${ }^{7}$ Ficha do filme em IMDb [2019f].

${ }^{8}$ Ficha do filme em IMDb ([2019g]).

${ }^{9}$ Este em parceria com outros dois cineastas, Ozualdo Candeias e Luís Sérgio Person. O filme é constituído por três histórias independentes, cada uma dirigida por um cineasta diferente. Ficha do filme em IMDb [2019h].

${ }^{10}$ Finalizado em 1970, o filme foi submetido a censura, porém teve seu lançamento completamente proibido até 1986 , quando foi liberado com outro nome, $O$ despertar da besta. Ficha do filme em IMDb ([2019i]).
} 
censores da época exigiram que o final fosse redublado com falas escritas por eles mesmos. Nesse novo final Zé do Caixão se arrepende de seus pecados e acolhe Deus. Todavia, o que aconteceu com $O$ ritual dos sádicos foi pior, a obra foi completamente proibida, acusada de apologia às drogas. Esse episódio seria fundamental para o declínio da carreira de Mojica. Além do total prejuízo por não poder lançar seu filme, os produtores se afastaram dele, com medo de financiar películas que não saíssem dos porões da censura.

\section{Análise de À meia-noite levarei sua alma}

A metodologia utilizada foi a análise fílmica, a fim de averiguar como alguns aspectos da matriz religiosa brasileira foram construídos e reproduzidos no filme À meia-noite levarei sua alma. Para isso, foram analisadas cenas do filme nas quais aspectos dessa matriz religiosa brasileira se manifesta.

Já em uma de suas primeiras cenas, logo após os créditos de abertura, o filme introduz uma mulher (Eucaris Moraes) que remete a uma mistura de cigana e bruxa. Ela se dirige ao público (Figura 1) e anuncia a ação que está por vir:

Bruxa: Péssima noite para vocês, meus amiguinhos corajosos. Guardem bem estas palavras. A todos aqueles que viram um velório, o rosto pálido de um cadáver, a todos aqueles que não acreditam em almas penadas, aos que ao saírem deste cinema e tiverem que passar por ruas escuras, sozinhos, ainda há tempo! Não assistam a este filme! Vão embora! Tarde demais! Vocês não acreditaram. Querem mostrar uma coragem que não existe? Pois então fiquem! Sofram! Assistam... À meia-noite levarei sua alma!

Essas palavras são proferidas enquanto a mulher passeia por um cenário com vários elementos que remetem a rituais de magia, como velas, crânios e caldeiras, mas também tem elementos católicos, como uma imagem de Jesus Cristo crucificado. Nessa primeira cena, através da composição do cenário já se denota o sincretismo religioso. A mulher provoca os céticos e desafia os espectadores. De repente, o relógio soa a meia-noite e ela professa que é tarde demais, finalizando com uma risada estridente. 
Figura 1 - A bruxa/cigana que provoca os espectadores

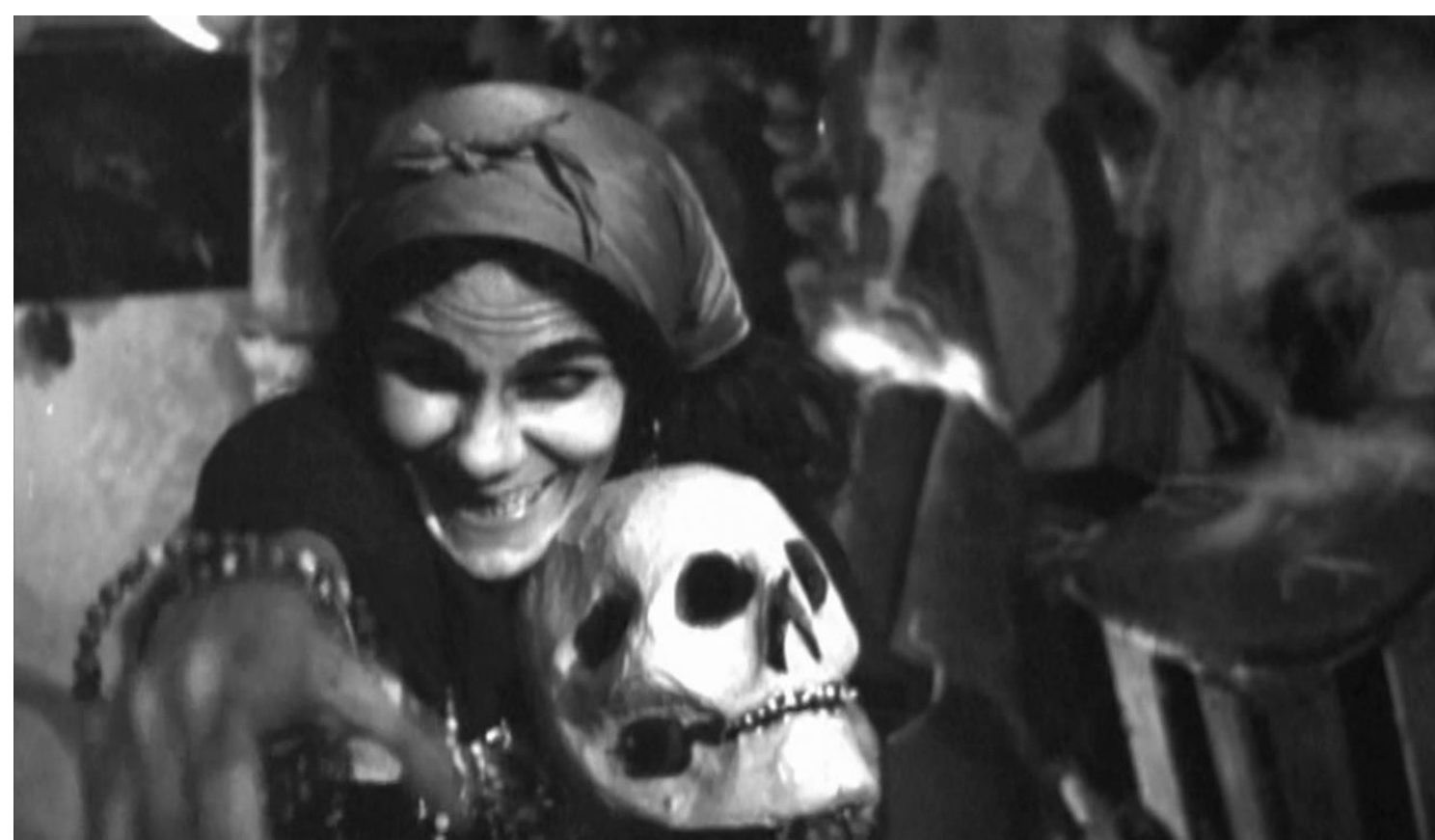

Fonte: À Meia-Noite Levarei sua Alma (1964), adaptado pelos autores.

Essa primeira cena já traz consigo diversos elementos religiosos utilizados tanto no cenário como na construção do imaginário que o filme o evoca. No que toca ao cenário, se percebem esses objetos utilizados muitas vezes em rituais de magia, como velas e crânios. Eles têm uma relação direta com o imaginário do público em relação a isso. A mulher que fala diretamente com o público evoca toda uma tradição de bruxas construída durante séculos e reafirmada no Brasil desde o período colonial. Essa construção de imaginário se relaciona tanto com histórias antigas envolvendo rituais de magia quanto com a construção do tipo ideal de bruxa pela cultura pop, remetendo a outros filmes e livros estrangeiros. Do mesmo modo, esse tipo de personagem é conhecido nas histórias em quadrinhos de horror e em séries televisivas como "o anfitrião", um personagem que serve apenas para introduzir as histórias a serem contadas (MELO, 2010). Posteriormente, no filme, ficará claro, porém, que essa bruxa é na verdade uma cigana, que lê a sorte de outros personagens e percebe as intenções maléficas de Zé do Caixão. Esse início, todavia, já constrói um clima que brinca com as crenças das pessoas, principalmente em relação a espíritos que vagueiam pela noite. Ao invocar esse imaginário das almas penadas que aparecem durante a noite em vielas, o monólogo visa construir sua relação com o espectador que estava no cinema, à noite, e depois teria que voltar para casa e passar por ruas escuras. 
Após essa introdução feita pela cigana, o espectador é apresentado a história central da obra. Depois de voltar de um enterro, o protagonista, Zé do Caixão (José Mojica Marins), chega em casa e pede a sua esposa Lenita (Valéria Vasquez) que sirva o jantar. Ao perceber que não há carne, ele a questiona:

Zé: Ué, cadê a carne?

Lenita: Hoje não tem, você se esqueceu que é sexta-feira santa?

Zé: Que me importa que seja sexta-feira dos santos ou do demônio? Eu vou buscar o que eu quero e nenhum carola vai intervir! Hoje eu como carne, nem que seja de gente!

Lenita: Cuidado, Zé! O diabo tenta!

Zé: Se eu o encontrar, vou convidá-lo para jantar.

Na sequência (Figura 2) vemos Zé comendo um pedaço de carne de cordeiro em frente à janela, enquanto, na rua, passa a procissão. Ele zomba dos transeuntes. Um padre para diante dele e faz o sinal da cruz, ao que Zé responde lhe oferecendo um pedaço de carne. Posteriormente, o coveiro ainda obrigará um dos homens num bar a comer o que resta do pedaço de carne.

Figura 2 - Zé come um pedaço de cordeiro e zomba dos padres na procissão.

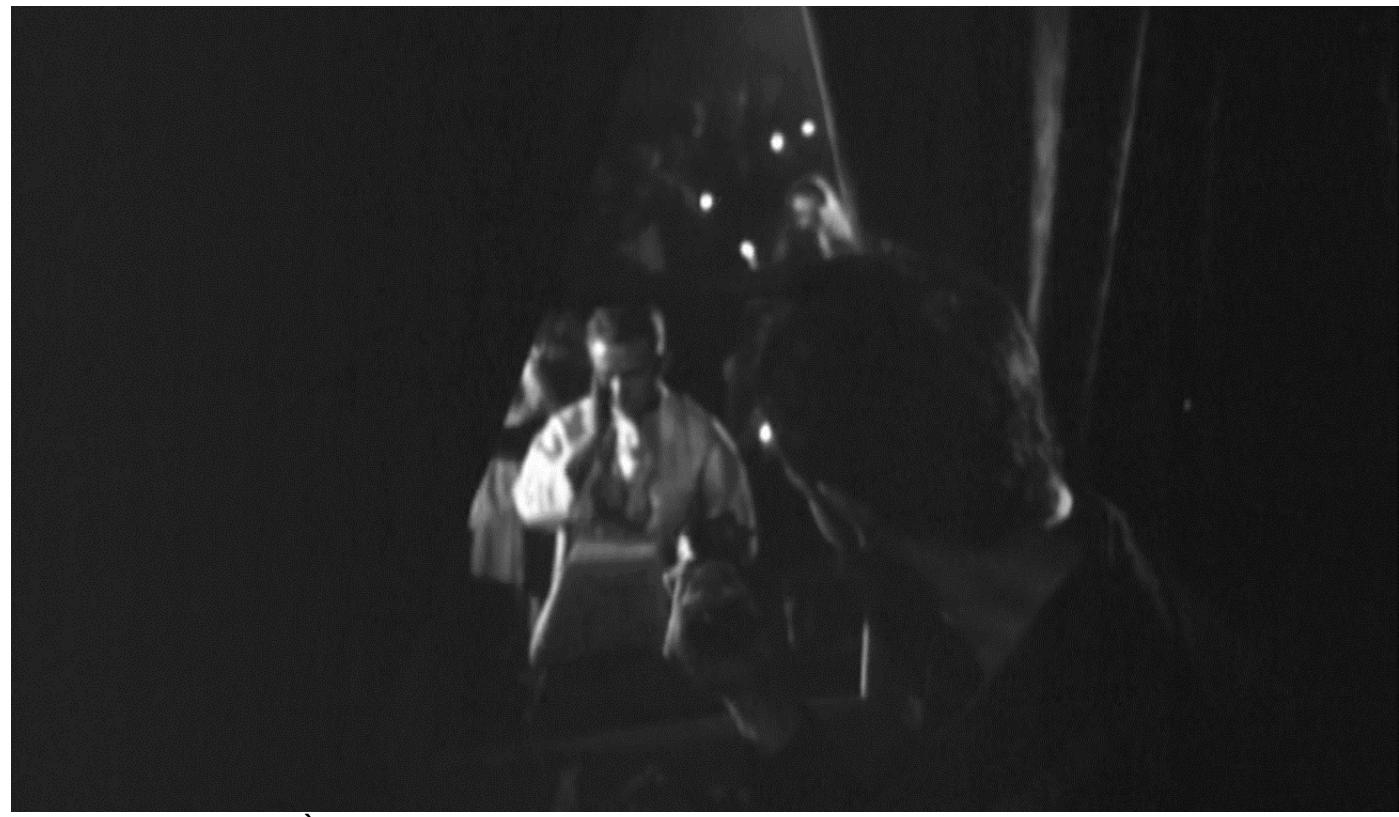

Fonte: À Meia-Noite Levarei sua Alma (1964), adaptado pelos autores.

A zombaria de Zé em relação a fé alheia é reafirmada em diversos momentos durante o filme. Em relação ao cristianismo, as críticas são contundentes e a profanação de 
algumas imagens têm seu ápice como numa cena em que Zé utiliza de uma coroa de espinhos retirada da imagem de Jesus para ferir o rosto de um homem em uma briga. 0 coveiro é qualificado como emissário do capeta pelos moradores locais e a eles se refere sempre como povinho, carolas, tolos, ou adjetivos que indiquem inferioridade. Zé, por diversas vezes, assume um discurso nietzschiano de superioridade diante do resto do povo, que, para ele, é atrasado e se apega a símbolos religiosos e crenças infundadas, criadas pela ignorância.

O tom provocativo do começo do filme, quando a cigana se dirige diretamente ao público espectador, é indiretamente retomado em diversas cenas da obra. Tanto pelo diálogo, com as críticas ferozes de Zé, quanto por imagens, com a narrativa visual que transforma itens religiosos em armas (como na cena da coroa de espinhos), a religiosidade do público é constantemente provocada. A crítica não se atém apenas ao cristianismo, mas também a diversos tipos de crenças e superstições. Zé debocha da cigana que adivinha o futuro e em outra cena profana um local onde estão oferendas de despacho, roubando o dinheiro que está no local.

O medo que se articula no filme é fundamentado diretamente na questão da crença. O personagem de Zé é o único que não teme nada, domina os outros moradores e exerce sobre eles sua força, independência e inteligência para conquistar seus objetivos. Os moradores, por sua vez, são mostrados sempre como excessivamente temerosos, não comem carne na sexta-feira santa, participam da procissão e têm medo de sair na rua à noite, no dia dos mortos. Sempre pelos cantos cochichando, veem Zé como alguém em conluio com o demônio. As mulheres temem seus modos e os homens que o desafiam são facilmente espancados e humilhados. Zé é visto como um ser semi-demoníaco, sempre pronto a causar infortúnios e, com facilidade, subjugar suas vítimas, maltratando-as de diversas formas.

Por outro lado, o medo também atinge o cético Zé. Primeiro, na cena em que uma tempestade atinge sua casa. Desafiando o sobrenatural, Zé professa um discurso niilista, pedindo por provas de que é culpado por seus crimes. Nesse momento, ele demonstra uma pontada de arrependimento, mas logo desvia sua culpa para as próprias vítimas. 0 julgamento vem, porém, no ato final, quando o medo atinge Zé de vez. Ele percebe que estava enganado na sua descrença e passa a temer o sobrenatural. Mas agora é tarde e é chegada a hora de sua punição.

Após todo tipo de provocação e polêmica, o final do filme vai em um caminho contrário e traz a punição ao coveiro. Em uma tempestade no dia dos mortos, as almas 
daqueles a quem o protagonista prejudicou voltam para se vingar e matá-lo. A procissão agora é a dos mortos (Figura 3), que subjugam o até então incrédulo Zé.

Figura 3 - A procissão dos mortos

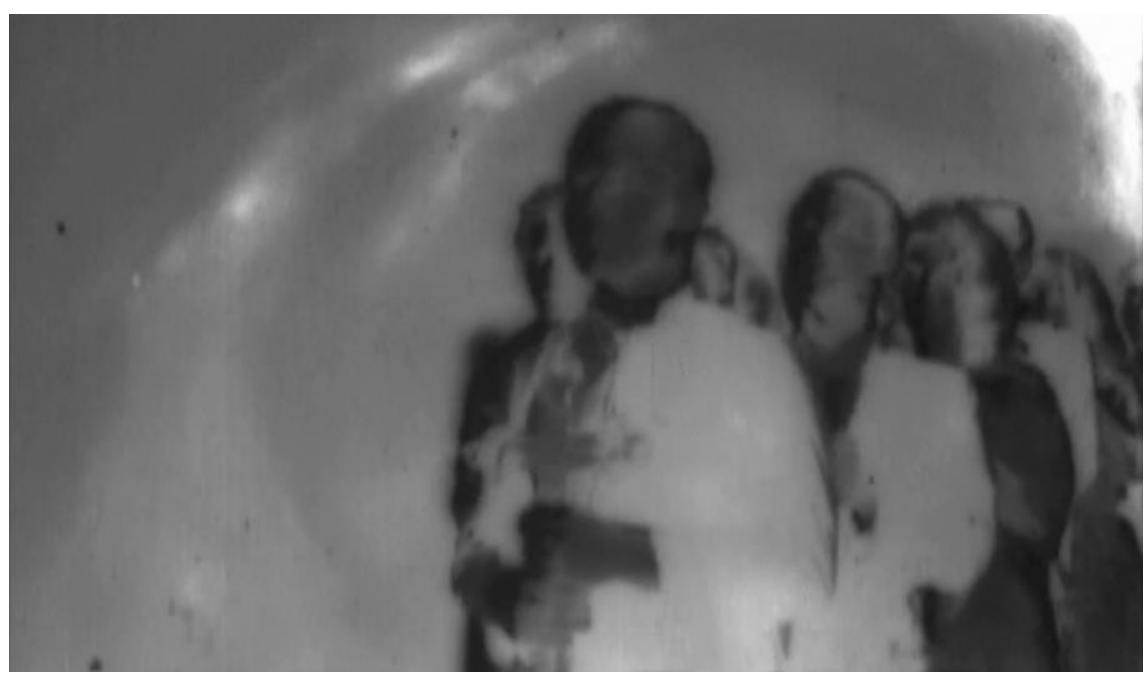

Fonte: À Meia-Noite Levarei sua Alma (1964), adaptado pelos autores.

Apesar de todo tipo de blasfêmia e crítica às religiões durante a película, o final não abre espaço para uma interpretação que não seja a de que Zé estava errado todo esse tempo. Afinal, tudo aquilo que ele não acreditava existe e ainda aparece para puni-lo. No fim, os moradores locais, que temiam quebrar seus ritos religiosos estavam certos e Zé, o niilista com ar de superior, estava completamente errado. Sua profanações e crimes são punidos com uma morte horrível. Na cena que fecha o filme, o corpo inerte de Zé jaz entre o túmulos do cemitério, com os olhos esbugalhados, apavorado com o que recém vira11.

Mojica joga inteligentemente com o espectador. 0 provoca suscitando todos os seus medos em relação ao sobrenatural, blasfema contra suas crenças, mas no final o alivia respondendo que ele está certo em temer o que vem do além. Esse jogo entre religiosidade e medo foi um dos fatores que mais gerou polêmica em relação ao filme e foi um dos responsáveis diretos por seu sucesso.

\footnotetext{
${ }^{11}$ Apesar do filme ter sofrido com a censura e o final de sua sequência, Esta noite encarnarei no teu cadáver, ter sido mudado pelos censores por questões morais, em À meia-noite levarei sua alma, essa solução moralista religiosa é posta já por Mojica em seu roteiro.
} 


\section{Considerações Finais}

A cultura de um povo pode ser percebida através de diferentes prismas, sendo a análise de sua religiosidade um aspecto contundente a ser averiguado. Analisar uma obra pode ser um bom indicativo de como certos aspectos se relacionam dentro desse sistema religioso que fundamenta uma certa cultura. No caso de um filme de horror, é possível entender as relações entre os medos de determinados grupos e como certos assuntos atraem esse público. Em À meia-noite levarei sua alma, os medos e crenças desse grupo são constantemente confrontados, o que pode explicar seu sucesso e posterior estabelecimento do personagem Zé do Caixão como símbolo do horror no cenário nacional. Zé do Caixão se tornou personagem de histórias em quadrinhos, apresentador de tv líder de audiência, protagonista de vários filmes e figura notória no imaginário nacional. Famoso dentro do nicho de horror também fora do país, Zé do Caixão se tornou Coffin Joe nos Estados Unidos e recebeu prêmios e homenagens na Europa (BARCINSKI; FINOTTI, 2015).

Em À meia-noite levarei sua alma se estabeleceram diversos mecanismos que foram repetidos nos filmes posteriores, principalmente no que toca ao tema da religiosidade brasileira e a forte presença de elementos culturais do país, sempre dialogando com seu público. Nesse filme, o medo é evocado através do escárnio com as crenças, da negação das religiões. Todavia, o final entrega ao espectador o alívio, o restabelecimento da ordem e a punição do herege. Suas crenças são reafirmadas e o público é satisfeito. As provocações de Mojica são feitas durante grande parte do longa-metragem, para serem castigadas no final. Mas retornam no filme seguinte, para o deleite da audiência.

\section{Referências}

ACOM, Ana Carolina; MORAES, Denise Rosana da Silva. Zé do caixão: surrealismo e horror caipira. In: CONGRESSO INTERNACIONAL HUMANIDADES NAS FRONTEIRAS, 1., 2017, Foz do Iguaçu. Anais [...]. Foz do Iguaçu: UNILA-PR, 2017. p. 29-49. Disponível em: https://dspace.unila.edu.br/123456789/3542. Acesso em: 18 abr. 2019.

ARAÚJO, Danielle Regina Wobeto de. Um "cartório de feiticeiras": direito e feitiçaria na vila de curitiba (1750-1777). 2016. Tese (Doutorado em Direito) - Programa de PósGraduação em Direito, Universidade Federal do Paraná, Curitiba, 2016.

BARCINSKI, André; FINOTTI, Ivan. Zé do Caixão: maldito - a biografia. 2. ed. Rio de Janeiro: DarkSide Books, 2015. 
ESCOSTEGUY, Ana Carolina. Os estudos culturais. In: HOHLFELDT, Antonio; MARTINO, Luiz; FRANÇA, Vera Veiga (org.). Teorias da comunicação: conceitos, escolas e tendências. 15. ed. Petrópolis: Vozes, 2015.

BITTENCOURT FILHO, José. Matriz religiosa brasileira: religiosidade e mudança social. Petrópolis: Vozes, 2003.

FREYRE, Gilberto. Casa-grande e senzala. 51. ed. São Paulo: Global, 2006.

FRANCO JÚNIOR, Hilário. Raízes medievais do brasil. Revista USP, São Paulo, n. 78, p. 80 104, 2008.

IBGE. Censo demográfico 2010: características gerais da população, religião e pessoas com deficiência. Rio de Janeiro: IBGE, 2010.

IMDB. À meia noite levarei sua alma (1964). [S. l.], [2019a]. Disponível em: https://www.imdb.com/title/tt0059440/. Acesso em: 18 ab. 2019.

IMDB. Deus e o diabo na terra do sol (1964). [S. l.], [2019b]. Disponível em: https://www.imdb.com/title/tt0058006/. Acesso em: 18 ab. 2019.

IMDB. 0 dragão da maldade contra o santo guerreiro (1969). [S. l.], [2019c]. Disponível em: https://wwcw.imdb.com/title/tt0064256/. Acesso em: 18 ab. 2019.

IMDB. A sina do aventureiro (1958). [S. l.], [2019d]. Disponível em: https://www.imdb.com/title/tt0163238/. Acesso em: 18 ab. 2019.

IMDB. Meu destino em tuas mãos (1963). [S. l.], [2019e]. Disponível em: https://www.imdb.com/title/tt0191278/. Acesso em: 18 ab. 2019.

IMDB. Esta noite encarnarei no teu cadáver (1967). [S. l.], [2019f]. Disponível em: https://www.imdb.com/title/tt0060380/. Acesso em: 18 ab. 2019.

IMDB. 0 estranho mundo de Zé do Caixão (1968). [S. l.], [2019g]. Disponível em: https://www.imdb.com/title/tt0062943. Acesso em: 18 ab. 2019.

IMDB. Trilogia de terror (1968). [S. l.], [2019h]. Disponível em: https://www.imdb.com/title/tt0063721/. Acesso em: 18 ab. 2019.

IMDB. 0 ritual dos sádicos (1970). [S. l.], [2019i]. Disponível em: https://www.imdb.com/title/tt0062690. Acesso em: 18 ab. 2019.

MELO, Marcelo Briseno Marques de. Zé do caixão: personagem de horror. 2010. Tese (Doutorado em Comunicação Social) - Programa de Pós-Graduação em Comunicação Social, Universidade Metodista de São Paulo, São Bernardo do Campo, 2010.

PEREIRA, Otaviano José. Salva tua alma! (a trajetória do cristianismo da igreja como negação do corpo e dos impasses do clero contemporâneo). 1991. Tese (Doutorado em Filosofia e História da Educação) - Universidade Estadual de Campinas, Campinas, 1991. 
SENADOR, Daniela Pinto. Das primeiras experiências ao fenômeno zé do caixão: um estudo sobre o modo de produção e a recepção dos filmes de josé mojica marins entre 1953 e 1967. 2008. Dissertação (Mestrado em Ciências da Comunicação) - Escola de Comunicações e Artes, Universidade de São Paulo, São Paulo, 2008.

WILLIAMS, Raymond. Política do modernismo. São Paulo: Unesp, 2011.

\title{
Aspects of Brazilian Religiousness in At Midnight l'll Take your Soul
}

\begin{abstract}
This article attempts to highlight aspects of Brazilian religiousness in the film At Midnight I'll Take Your Soul, directed by José Mojica Marins and released in 1964, as well as understanding how these elements are utilized in the work to cause fear in the audience. The paper employs Cultural Studies to understand the process of establishment of the Brazilian religiosity in our country's popular imagination. Finally, a few scenes in the film were chosen for discussion due to the presentation of these religious elements, so that they could be investigated through film analysis and so that one could understand how these elements are articulated and represented. In conclusion, it can be seen that the film uses the beliefs of its viewers to provoke their curiosity and ecstasy regarding the saga of Coffin Joe.
\end{abstract}

\section{Keywords}

At Midnight I'll Take Your Soul. José Mojica Marins. Brazilian religiousness. Cultural Studies. Cinema.

\section{Autor correspondente}

Giancarlo Backes Couto giancouto@hotmail.com

COUTO, Giancarlo Backes; GERBASE, Carlos. Aspectos da religiosidade em À Meia-Noite Levarei Sua Alma. Intexto, Porto Alegre, n. 52, e-92019, jan./dez. 2021. DOI: http://dx.doi.org/10.19132/18078583202152.92019 